\title{
REFERENCES
}

Ball, E. G. \& Chen, T. T. (1933). J. biol. Chem. 102, 691. Baumann, E. (1876). Pflüg. Arch. ges. Physiol. 13, 285.

Baumann, E. (1878). Ber. dtsch. chem. Ges. 11, 1907.

Baumann, E. \& Herter, E. (1877-8). Hoppe-Seyl. Z. 1, 244.

Brieger, L. (1879). Arch. Anat. Physiol., Lpz., Suppl. Bd. p. 65.

Dietering, H. (1938). Arch. exp. Path. Pharmak. 188, 493.

Di Somma, A. A. (1940). J. biol.' Chem. 183, 277.

Dodgson, K. S., Garton, G. A., Stubbs, A. L. \& Williams, R. T. (1948). Biochem. J. 42, 357.

Dodgson, K. S., Garton, G. A. \& Williams, R. T. (1947). Biochem. J. 41, Proc. l.

Drummond, J. C. \& Finar, I. L. (1938). Biochem. J. 32, 79. Florence, G. \& Schapira, G. (1943). Bull. Soc. Chim. biol., Paris, 25, 1054.
Hanson, S. W. F., Mills, G. T. \& Williams, R. T. (1944). Biochem. J. 38, 274.

Masing, A. (1882). Cited by Ellinger, A. (1923). In Handbuch der experimentellen Phammakologie, 1, 942. Berlin: Springer.

Nelson, J. M. \& Dawson, C. R. (1944). Advanc. Enzymol. 4, 99.

Pauling, L. C. (1945). The Nature of the Chemical Bond, p. 325. London and New York: Cornell University Press. Porteous, J. W., Smith, J. N. \& Williams, R. T. (1947). XIth Int. Congr. pure and appl. Chem., Lond. (in the Press).

Sera, Y. (1913). Hoppe-Seyl. Z. 88, 460.

Sera, Y. (1914). Hoppe-Seyl. Z. 92, 261.

Williams, R. T. (1938). Biochem. J. 32, 878.

\section{Metabolism of Derivatives of Toluene}

\author{
1. THE METABOLISM OF ACETOTOLUIDIDES IN THE RABBIT \\ BY H. G. BRAY AND W. V. THORPE \\ Department of Physiology, Medical School, University of Birmingham
}

(Received 2 February 1948)

In an investigation of the metabolism of the acetotoluidides, Jaffe \& Hilbert (1888) found that all three isomers were oxidized in the dog and rabbit. $p$ Acetotoluidide was shown to be converted almost quantitatively to $p$-acetamidobenzoic acid in both animals; similarly, $m$-acetamidobenzoic acid was isolated as a metabolite of $m$-acetotoluidide and it was suggested that an aminocresol might also be formed. $o$-Acetotoluidide gave rise in the dog to a compound claimed to be a methylbenzoxazolone. The constitution of this compound was not elucidated, but on treatment with ammonia in a sealed tube at $130-140^{\circ}$ it gave a compound melting at $148-150^{\circ}$ which appeared to be an aminocresol. Seven aminocresols were known to Jaffe \& Hilbert, but it is now apparent that the isomer they obtained was in fact 2-amino-m-cresol which was not again described until 37 years later (Hodgson \& Beard, 1925). The nature of the aminocresols formed as metabolites of acetotoluidides was of interest to us in view of the general rule concerning the position of entry of the hydroxyl group in biological hydroxylations which had been suggested by other investigations (e.g. Bray, Ryman \& Thorpe, 1947; Bray, Lake, Neale, Thorpe \& Wood, 1948). Consequently, we have carried out a further investigation of the fate of these compounds in the rabbit and included certain quantitative studies, the results of which are also reported here.

\section{EXPERIMENTAL}

\section{Materials and methods}

Materials. The acetotoluidides used in this study were prepared by the action of acetic anhydride upon the corresponding toluidines (Light and Co. Ltd.), the products being recrystallized from water. The reference compounds, 2amino-5-hydroxytoluene (6-amino- $m$-cresol) and 5-amino-2hydroxytoluene (5-amino-o-cresol), were prepared by the method of Noelting \& Cohn (1884), which involves the reductive fission of azo compounds prepared from benzenediazonium chloride and the appropriate cresol. The azo compounds were dissolved in $2 \mathrm{~N}-\mathrm{NaOH}$ and reduced by means of $\mathrm{Na}_{2} \mathrm{~S}_{2} \mathrm{O}_{4}$ : The properties of the compounds obtained agreed with those described in the literature.

Diet and feeding. The rabbits used were does of $2-3 \mathrm{~kg}$. weight. A constant diet of rabbit pellets, with water $a d$ lib., was given throughout the study, as previously described (Bray et al. 1947). The acetotoluidides were administered by stomach tube as suspensions in water. The $p$-isomer showed no toxic properties at a dose level of $0.5 \mathrm{~g}$. $/ \mathrm{kg}$., but, since at this dose level the $m$-isomer was noticeably toxic and $o$ acetotoluidide slightly so, these two compounds were usually administered at a dose level of $0 \cdot 25 \mathrm{~g} . / \mathrm{kg}$.

Estimation of diazotizable material. This was carried out in acetotoluidide urines as collected, and after hydrolysis under the conditions described by Bratton \& Marshall (1939). Compounds which might theoretically be included in the term 'diazotizable material' are aminocresols, with their glucuronides and ethereal sulphates, toluidines, and aminobenzoic acids. We found, however, that the two aminocresols 
isolated as metabolites of $o$ - and $m$-acetotoluidides gave no appreciable colour under the conditions of diazotization and coupling employed, and so made no significant contribution to the colour developed with either hydrolyzed or unhydrolyzed urine. We were not able to isolate glucuronides or ethereal sulphates of these compounds and their behaviour on diazotization and coupling is thus unknown. Since neither aminocresol is an o-aminophenol derivative, it would be expected that the colour given by the glucuronides or ethereal sulphates would be similar to that given by the parent compounds. However, these conjugates are found only in unhydrolyzed urine, and the amount of diazotizable material there is so small that it is in any case difficult to decide which compounds are responsible. In general, the colours obtained could be matched with relative ease against the colour developed from a standard solution of the corresponding aminobenzoic acid. The only diazotizable compounds, which are likely to make a contribution to the diazotizable material in hydrolyzed urine, are the toluidines and the aminobenzoic acids. The colours developed from these two types of compound cannot readily be matched, whereas the colours developed from hydrolyzed urine could in the majority of cases be readily compared with an aminobenzoic acid standard. This is indirect evidence for the absence of an appreciable amount of toluidines as is also the fact that there is reasonably good agreement between the results obtained from diazo estimations carried out on hydrolyzed urine and from estimations of ether-soluble acid, which determine the total acetamidobenzoic acids presentless the amount excreted as ester glucuronide. While these facts do not provide final proof that unchanged acetotoluidides (or toluidines) are not excreted as such, they strongly suggest that this is the case. Moreover, we were never able to isolate any of these compounds from acetotoluidide urines.

Aminobenzoic acid solutions were used as standards in all diazo estimations. A much longer time was required for maximum colour development with the 0 -isomer than with the other compounds (Bray et al. 1948).
Estimation of reducing substances. The method used was that previously described (Bray, Neale \& Thorpe, 1946a). The estimation was carried out only on unhydrolyzed urine, as aminocresols were found to reduce the Shaffer-Hartmann reagent and, in the case of $p$-acetotoluidide urines, we have found that the results obtained with urines passed after the administration of $p$-aminobenzoic acid were unreliable (Bray et al. 1948).

Estimation of ethereal sulphate. The method of Folin (1905-6) was used as before.

Estimation of ether soluble acid. The method used has already been described (Bray et al. 1946a). Under these conditions acetamidobenzoic acids may be quantitatively extracted and estimated. Since it was found that no phenolic material (i.e. aminocresols or their acetyl derivatives) was extracted during this procedure, the results of these estimations may be taken as giving the total oxidation to acetamidobenzoic acid less that excreted as ester glucuronide. The errors involved, owing to the fact that unacetylated aminobenzoic acids are not quantitatively extracted at the $\mathrm{pH}$ used, are small since the amounts excreted are very small.

\section{RESULTS}

\section{Quantitative studies}

Excretion of normal metabolites. On the diet used, it was found that the average daily excretion of ethereal sulphate ranged from 32 to $46 \mathrm{mg}$. $\mathrm{SO}_{3}$; of other-soluble acid (calculated as hippuric acid) from 709 to $913 \mathrm{mg}$., and of reducing material (calculated as glucuronic acid) from 224 to $307 \mathrm{mg}$.

Metabolism of p-acetotoluidide. The results of the estimations performed on $\boldsymbol{p}$-acetotoluidide urines are summarized in Table 1 . They strongly suggest that the oxidation to $p$-acetamidobenzoic acid is virtually complete, $96 \%$ of the dose being accounted for as

Table 1. Metabolites of $\mathrm{p}$-acetotoluidide in the rabbit

\begin{tabular}{|c|c|c|c|c|c|c|}
\hline \multirow[b]{2}{*}{ Rabbit } & \multirow[b]{2}{*}{$\begin{array}{l}\text { Dose level } \\
\text { (g./kg.) }\end{array}$} & \multirow[b]{2}{*}{$\begin{array}{l}\text { Ether- } \\
\text { soluble } \\
\text { acid }\end{array}$} & & \multirow[b]{2}{*}{$\begin{array}{l}\text { Ethereal } \\
\text { sulphate }\end{array}$} \\
\hline & & & $\begin{array}{c}\text { Ester } \\
\text { glucuronide }\end{array}$ & $\begin{array}{l}\text { 'Free' } \\
\text { amino } \\
\text { compounds }\end{array}$ & $\begin{array}{l}\text { 'Total' } \\
\text { amino } \\
\text { compounds }\end{array}$ & \\
\hline 121 & 0.5 & 84 & $5 \cdot 2$ & - & 92 & Nil \\
\hline 157 & $\begin{array}{l}0.25 \\
0.5 \\
0.5 \\
0.5\end{array}$ & $\frac{-}{78}$ & $\begin{array}{r}\overline{4 \cdot 8} \\
7 \cdot 8 \\
11 \cdot 6\end{array}$ & $\begin{array}{l}-\overline{0.3} \\
0.8 \\
0.9\end{array}$ & $\frac{-}{100}$ & $\frac{\text { Nil }}{-}$ \\
\hline 162 & $\begin{array}{l}0.5 \\
0.5\end{array}$ & - & $\begin{array}{l}9 \cdot 8 \\
7 \cdot 0\end{array}$ & $\begin{array}{l}1 \cdot 0 \\
0.9\end{array}$ & - & - \\
\hline 163 & $\begin{array}{l}0.25 \\
0.5 \\
0.5 \\
0.5\end{array}$ & $\frac{-}{\overline{80}}$ & $\begin{array}{r}8 \cdot 4 \\
12 \cdot 0 \\
7 \cdot 7 \\
12 \cdot 8\end{array}$ & $\begin{array}{l}- \\
1 \cdot 0 \\
0 \cdot 8 \\
1 \cdot 3\end{array}$ & $\frac{\bar{z}}{\overline{100}}$ & $\begin{array}{l}\text { Nil } \\
- \\
-\end{array}$ \\
\hline 165 & $\begin{array}{l}0.5 \\
0.5\end{array}$ & $\begin{array}{l}77 \\
80\end{array}$ & $\frac{6 \cdot 3}{-}$ & $\begin{array}{r}0.4 \\
1 \cdot 1\end{array}$ & $\begin{array}{r}83 \\
100\end{array}$ & - \\
\hline 166 & 0.5 & 77 & $9 \cdot 4$ & $0 \cdot 3$ & 94 & - \\
\hline 170 & $\begin{array}{l}0.5 \\
0.5\end{array}$ & 78 & $\begin{array}{r}17 \cdot 9 \\
20 \cdot 8\end{array}$ & $\begin{array}{l}0.3 \\
0.9\end{array}$ & $\begin{array}{r}95 \\
100\end{array}$ & - \\
\hline Average & - & 79 & $10 \cdot 0$ & 0.8 & 96 & Nil \\
\hline
\end{tabular}


this compound by diazo estimation, and $88 \%$ as the sum of the ether-soluble acid $(\mathbf{7 8} \%)$ and ester glucuronide (10\%). $p$-Acetotoluidide causes no increase in ethereal-sulphate excretion, as we anticipated, since Hammerbacher (1884) found the same for $p$-toluidine in the dog, and we showed that $p$ aminobenzoic acid had no effect upon etherealsulphate excretion in the rabbit (Bray et al. 1948). The amount of deacetylation which occurs is very small. estimation. Attempts to isolate this compound have been unsuccessful, possibly because of such instability. A similar result was observed in the case of sulphapyridine, where there is no possibility of the formation of an ester glucuronide, and yet unhydrolyzed sulphapyridine urine had a reducing value greater than normal. It is possible that this may have been due to either $(a)$ the instability of the glucuronide of hydroxysulphapyridine, a metabolite of the drug (Bray, Neale \& Thorpe, 1946b),

Table 2. Metabolites of $\mathrm{m}$-acetotoluidide in the rabbit

\begin{tabular}{|c|c|c|c|c|c|}
\hline \multirow[b]{2}{*}{ Rabbit } & \multirow[b]{2}{*}{$\begin{array}{l}\text { Dose level } \\
\text { (g./kg.) }\end{array}$} & \multicolumn{4}{|c|}{ Percentage of dose excreted as } \\
\hline & & $\begin{array}{l}\text { Ether- } \\
\text { soluble } \\
\text { acid }\end{array}$ & $\begin{array}{l}\text { 'Free' } \\
\text { amino } \\
\text { compounds }\end{array}$ & $\begin{array}{l}\text { 'Total' } \\
\text { amino } \\
\text { compounds }\end{array}$ & $\begin{array}{l}\text { Ethereal } \\
\text { sulphate }\end{array}$ \\
\hline 121 & $\begin{array}{l}0.25 \\
0.25\end{array}$ & $\begin{array}{l}36 \\
34\end{array}$ & $\begin{array}{l}0 \cdot 3 \\
\text { Tr. }\end{array}$ & $\begin{array}{l}23 \\
27\end{array}$ & $\overline{-}$ \\
\hline 153 & $\begin{array}{l}0.25 \\
0.25\end{array}$ & $\begin{array}{l}\mathbf{3 0} \\
\mathbf{3 4}\end{array}$ & - & 25 & - \\
\hline 154 & $\begin{array}{l}0.25 \\
0.25\end{array}$ & $\begin{array}{l}31 \\
19\end{array}$ & - & $\begin{array}{l}22 \\
26\end{array}$ & $\overline{-}$ \\
\hline 157 & $\begin{array}{l}0.25 \\
0 \cdot 25 \\
0 \cdot 25\end{array}$ & $\begin{array}{l}49 \\
48 \\
42\end{array}$ & $\begin{array}{l}\text { Tr. } \\
\text { Tr. }\end{array}$ & $\begin{array}{l}28 \\
26 \\
-\end{array}$ & $\begin{array}{l}9 \\
--\end{array}$ \\
\hline 163 & $\begin{array}{l}0.25 \\
0.25 \\
0.25\end{array}$ & $\begin{array}{l}29 \\
27 \\
27\end{array}$ & $\begin{array}{l}\text { Tr. } \\
\text { Tr. } \\
-\end{array}$ & $\begin{array}{l}25 \\
30 \\
-\end{array}$ & $\frac{10}{-}$ \\
\hline 173 & $\begin{array}{l}0.25 \\
0.25 \\
0.25 \\
0.25\end{array}$ & $\begin{array}{l}24 \\
37 \\
31 \\
27\end{array}$ & $\begin{array}{l}\text { Tr. } \\
\text { Tr. } \\
-\end{array}$ & $\begin{array}{l}18 \\
27 \\
- \\
-\end{array}$ & $\frac{10}{-}$ \\
\hline Average & - & 34 & Tr. & 25 & 10 \\
\hline
\end{tabular}

Metabolism of m-acetotoluidide. Table 2 summarizes the results of estimations carried out on the urine of rabbits which had received $m$-acetotoluidide. Since it is concluded that the results obtained from the estimation of total diazotizable material are due entirely to $m$-aminobenzoic acid, $25 \%$ of the dose appears to be oxidized to this compound, a value agreeing reasonably well with that obtained from the estimation of ether-soluble acid (34\%). The value obtained from the diazo estimation is probably the more accurate since it does not involve 'base: line' values. The results of the estimations of reducing material are difficult to interpret and are not included in Table 2. In ten experiments the percentage of $m$-acetotoluidide excreted, apparently conjugated as ester glucuronide, ranged from 10 to 25 (average $16 \%$ ). It is unlikely that this is a true value, since the diazo values should indicate the total extent of oxidation to $m$-acetamidobenzoic acid, i.e. should approximate to ether-soluble acid plus ester glucuronide. Three reasons may be suggested for the high reducing values obtained, but we have been unable to obtain direct proof of any of them. (i) It is possible that the glucuronide of 5-amino-m-cresol may be unstable under the conditions used for which might break down to glucuronic acid and hydroxysulphapyridine, which is itself reducing, or (b) reducing properties of the glucuronide itself, though these may have been due to $(a)$. It may be significant that we were not able to isolate this glucuronide, in order to determine whether these suggestions have any foundation in fact. (ii) The second reason, which may be suggested to account for the high reducing values, is that $m$-acetotoluidide might have some effect upon carbohydrate meta. bolism. A similar effect was observed in connexion with $o$-acetotoluidide (see p. 214), but we have been unable so far to study the problem further. (iii) 5Amino-o-cresol reduces the Shaffer-Hartmann reagent, but, since we have been unable to detect the free compound in $m$-acetotoluidide urines, it seems likely that it is only excreted in conjugated form.

Metabolism of o-acetotoluidide. This study gave results qualitatively similar to those on the $m$ isomer. It may be concluded from the diazo estimations (Table 3) that $6 \%$ of the dose is oxidized to anthranilic acid. This agrees reasonably well with the results obtained from the determinations of ether-soluble acid, though the latter cannot be regarded as precise since $8 \%$ of a dose of $600 \mathrm{mg}$. 
Table 3. Metabolites of o-acetotoluidide in the rabbit

\begin{tabular}{|c|c|c|c|c|c|}
\hline \multirow[b]{2}{*}{ Rabbit } & \multirow[b]{2}{*}{$\begin{array}{l}\text { Dose level } \\
\text { (g./kg.) }\end{array}$} & \multicolumn{4}{|c|}{ Percentage of dose excreted as } \\
\hline & & $\begin{array}{c}\text { Ether- } \\
\text { soluble } \\
\text { acid }\end{array}$ & $\begin{array}{l}\text { 'Free' } \\
\text { amino } \\
\text { compounds }\end{array}$ & $\begin{array}{l}\text { 'Total' } \\
\text { amino } \\
\text { compounds }\end{array}$ & $\begin{array}{l}\text { Ethereal } \\
\text { sulphate }\end{array}$ \\
\hline 121 & $\begin{array}{l}0 \cdot 25 \\
0 \cdot 25\end{array}$ & $\begin{array}{l}3 \cdot 6 \\
3 \cdot 4\end{array}$ & $\begin{array}{l}7 \cdot 2 \\
5 \cdot 2\end{array}$ & $\begin{array}{l}6 \cdot 4 \\
6 \cdot 2\end{array}$ & 28 \\
\hline 153 & $\begin{array}{l}0 \cdot 25 \\
0 \cdot 25\end{array}$ & $\begin{array}{l}6 \cdot 9 \\
6 \cdot 8\end{array}$ & $\begin{array}{l}5 \cdot 7 \\
5 \cdot 0\end{array}$ & $\begin{array}{l}5 \cdot 9 \\
6 \cdot 5\end{array}$ & - \\
\hline 154 & $\begin{array}{l}0 \cdot 25 \\
0 \cdot 25\end{array}$ & $\begin{array}{l}18 \cdot 7 \\
16 \cdot 8\end{array}$ & $\begin{array}{l}4 \cdot 7 \\
4 \cdot 8\end{array}$ & $\begin{array}{l}6 \cdot 3 \\
5 \cdot 8\end{array}$ & - \\
\hline 157 & 0.25 & 一 & - & 一 & 30 \\
\hline 163 & $0 \cdot 25$ & - & - & - & 37 \\
\hline 173 & $\begin{array}{l}0 \cdot 25 \\
0 \cdot 25 \\
0 \cdot 25\end{array}$ & $\begin{array}{r}8 \cdot 5 \\
7 \cdot 1 \\
16 \cdot 0\end{array}$ & $\begin{array}{l}8 \cdot 2 \\
5 \cdot 5 \\
4 \cdot 5\end{array}$ & $\begin{array}{l}7 \cdot 5 \\
\dot{0} \cdot 9 \\
5 \cdot 1\end{array}$ & I \\
\hline Average & - & $7 \cdot 5$ & $5 \cdot 6$ & $6 \cdot 3$ & 32 \\
\hline
\end{tabular}

corresponds to an amount of acid (58 mg. hippuric acid) much less than the variations which occur in the normal 'base-line' values. Indeed, the excretion of ether-soluble acid in the $24 \mathrm{hr}$. period after the administration of $m$-acetotoluidide was in some cases actually within the normal range. Estimations of reducing value carried out on unhydrolyzed $o$ acetotoluidide urine gave results corresponding to conjugation of $25-68 \%$ (average $42 \%$ ) of the dose as ester glucuronide. It seems unlikely, from the agreement between the results of the diazo estimations and determinations of ether-soluble acid, that the reducing value actually represents ester-glucuronide excretion, and the explanations suggested in the case of the $m$-isomer may apply here also. Free 6amino- $m$-cresol was not detected in 0 -acetotoluidide urines. We were also unable to isolate a glucuronide in order to test the hypothesis based on its instability. The fact that in one rabbit the increased excretion of reducing material (approximately twice the normal value) persisted for 4 days after dosing is in accordance with the suggestion that the high reducing values observed are due to some more general influence upon metabolism, e.g. of carbor hydrate. In other rabbits the excretion of reducing material was restored to normal during the second $24 \mathrm{hr}$. We were unable to determine the nature of the reducing material excreted. In none of the rabbits was it accompanied by ketonuria, nor was it fermentable by yeast. We were unable to isolate a crystalline phenylosazone. There was little difference between the diazo results obtained with unhydrolyzed and hy drolyzed urine. The percentage of the dose excreted unacetylated was greater with o-acetotoluidide than with the other isomers. When anthranilic acid itself is administered, no acetylation appears to occur (Bray et al. 1948). A considerable percentage of 0 -acetotoluidide is hydroxylated and excreted conjugated with sulphate. This is in agreement with
Hammerbacher's (1884) observation that $o$-toluidine caused an increase in excretion of ethereal sulphate in the dog.

\section{Qualitative studies}

o-Acetotoluidide. The urine of rabbits which had received this compound ( $1 \mathrm{~g}$. each) was collected for $24 \mathrm{hr}$. after dosage, acidified with conc. $\mathrm{HCl}(0 \cdot 1 \mathrm{vol}$.) and continuously extracted with ether for $24 \mathrm{hr}$. In this way a small amount of syrupy material (1 g. from urine of five rabbits) was obtained. This gave a slightly positive diazo reaction, which was much more intense after acid hydrolysis. From the syrup a small amount (10 mg.) of crystalline material (m.p. $184^{\circ}$ ) was isolated, and shown to be identical with authentic acetylanthranilic acid (m.p. $185^{\circ}$ ).

The urine was then acidified further with $0 \cdot 1$ vol. conc. $\mathrm{HCl}$ and hydrolyzed by boiling for $1 \mathrm{hr}$. The pH was adjusted to 8 and the urine continuously extracted with ether for $24 \mathrm{hr}$. A dark syrup was obtained which gave an intense red-purple colour with ferric chloride. Purification by dissolving in water, treatment with charcoal and evaporation of the filtrate gave colourless needles, darkening in air. m.p. $178^{\circ}$ alone or mixed with 6-amino-m-cresol (m.p. $178^{\circ}$ ). This compound gives, on diazotization and coupling with dimethyl- $\alpha$-naphthylamine or $N$ (1-naphthyl)-ethylenediamine dihydrochloride, a transient blue colour, but on long standing a violet colour develops. These colours are feeble compared with those obtained from aminobenzoic acids and in solutions of $10-20 \mathrm{mg} . / 100 \mathrm{ml}$. are almost negligible. The yield of 6-amino-m-cresol cannot be definitely stated. Most procedures for isolation yielded about $100 \mathrm{mg}$. from a $1 \mathrm{~g}$. dose, but owing to the great sensitivity of the compound to oxidation by air this does not represent the entire yield. In view of its instability it is reasonable to suggest that it is actually excreted as its $N$-acetyl derivative, though 
we could not prove this directly, owing to its feeble diazotization and poor coupling properties. No free aminocresol was detected and no other metabolite was isolated.

$o$-Acetotoluidide urine gave a strongly positive naphthoresorcinol reaction and attempts were made to isolate a glucuronide (cf. Bray et al. 1947). These yielded only syrups which could not be crystallized, but from which, after hydrolysis, 6-amino-m-cresol was isolated.

$\mathrm{m}$-Acetotoluidide. The method used for the isolation of metabolites of this compound was essentially the same as with the $o$-isomer. Extraction of the acidified urine yielded crystalline $m$-acetamidobenzoic acid which was purified by treatment with charcoal and recrystallization from water. It melted at $248^{\circ}$ alone or mixed with an authentic specimen (m.p. $248^{\circ}$ ); yield, $20 \%$ of the dose. Extraction of the hydrolyzed urine gave a crystalline product, which after recrystallization from benzene had m.p. $174^{\circ}$ alone or mixed with synthetic 5-amino-o-cresol. Its identity was further confirmed by comparison of acetyl derivatives obtained by the action of acetic anhydride at ordinary temperature. These compounds melted at $178^{\circ}$ alone or mixed together. Yield, $30 \%$ of the dose. As with the aminocresol from $o$-acetotoluidide, it is probable that the acetyl derivative is the compound actually excreted.

p-Acetotoluidide. Extraction of acidified unhydrolyzed urine enabled $70 \%$ of the dose to be recovered as crystalline $p$-acetamidobenzoic acid. No other metabolite was isolated.

\section{DISCUSSION}

It can be seen that the results obtained in this investigation confirm in general those of Jaffe \& Hilbert (1888). In addition we were able to show the formation from $o$-acetotoluidide of anthranilic acid, of which only small part is a excreted acetylated. 5-Amino-o-cresol was isolated from hydrolyzed $m$ acetotoluidide urine. In the rabbit 0 -acetotoluidide gives rise chiefly to 6-amino-m-cresol, whereas it now appears that Jaffe \& Hilbert found 2-amino-mcresol to be the chief metabolite in the dog. It is of interest that we obtained oxidation products of both these types from $o$-aminobenzoic acid in the rabbit
(Bray et al. 1948), but we were unable to detect the vicinally substituted compound here. The configuration of the three aminocresols obtained by us, or by Jaffe \& Hilbert, are in accordance with the general rule that the entering hydroxyl group takes up a position ortho or para to the amino (or acetamido) group already present (see Bray et al. 1948).

The formation of benzoxazolone or its derivatives in vivo is of interest. To our knowledge only three such cases have been described, viz. from acetanilide and $o$-acetotoluidide ( $\mathrm{Jaffe} \&$ Hilbert, 1888), and from formanilide (Kleine, 1896-7). In all these studies the experimental animal was the dog. It would be of interest to determine whether any other animal is capable of ring formation of this type, since $o$-aminophenol compounds are common metabolites of amino compounds. There is a possibility that the benzoxazolone derivatives formed may be artifacts, since it is known that 0 -aminophenol (or its hydrochloride) and urea give rise to benzoxazolone when heated together at a high temperature (Sandmeyer, 1886; Williams, 1947). In all three instances where benzoxazolone was isolated the urine was first evaporated to dryness. Whether this treatment is drastic enough to deacetylate the o-aminophenol derivative and then condense it with urea appears doubtful, but this question is under investigation.

The quantitative results show an interesting gradation in metabolic behaviour, as can be seen in Table 4.

It is probable that the $N$-acetyl group in $p$-acetotoluidide remains intact throughout metabolism, since the degree of acetylation of the $p$-aminobenzoic acid excreted (at least $88 \%$ ) is very much greater than when this acid is itself ingested (4-21\%, Bray et al. 1948). It is not possible to say, with any certainty, whether this applies also to the other acetotoluidides, since other metabolites are also formed.

\section{SUMMARY}

1. The metabolism of 0 -, $m$ - and $p$-acetotoluidides in the rabbit has been studied.

2. o-Acetotoluidide is partly oxidized to anthranilic acid $(6 \%)$ and acetyl anthranilic acid $(1 \%)$; a considerable part of the remainder appears to be converted to 6-amino-m-cresol, which has been isolated. This latter compound is probably excreted as its

Table 4. Summary of metabolites of acetotoluidides in the rabbit

\begin{tabular}{|c|c|c|c|c|c|}
\hline \multirow[b]{2}{*}{ Isomer } & \multicolumn{5}{|c|}{ Average percentage of dose excreted as } \\
\hline & $\begin{array}{l}\text { Ether- } \\
\text { soluble } \\
\text { acid }\end{array}$ & $\begin{array}{c}\text { Ester } \\
\text { glucuronide }\end{array}$ & $\begin{array}{c}\text { 'Free' } \\
\text { diazotizable } \\
\text { material }\end{array}$ & $\begin{array}{c}\text { 'Total'* } \\
\text { diazotizable } \\
\text { material }\end{array}$ & $\begin{array}{l}\text { Ethereal } \\
\text { sulphate }\end{array}$ \\
\hline $\begin{array}{l}\text { ortho } \\
\text { meta } \\
\text { para }\end{array}$ & $\begin{array}{r}8 \\
\mathbf{3 4} \\
\mathbf{7 9}\end{array}$ & $\overline{-}$ & $\begin{array}{l}5 \cdot 6 \\
\text { Tr. } \\
0 \cdot 8\end{array}$ & $\begin{array}{r}6 \\
25 \\
96\end{array}$ & $\begin{array}{l}32 \\
10 \\
\text { Nil }\end{array}$ \\
\hline
\end{tabular}

* Assumed equivalent to total oxidation of $\mathrm{CH}_{3}$ group. 
$N$-acetyl derivative conjugated with glucuronic acid and sulphate. The extent of sulphate conjugation corresponds to $32 \%$ of the dose.

3. The metabolism of $m$-acetotoluidide is similar to that of the ortho isomer; $25 \%$ is oxidized to the corresponding $N$-acetamidobenzoic acid, and the only other metabolite detected was 5-amino-o-cresol which has been isolated. This is probably excreted as its $N$-acetyl derivative conjugated with glucuronic acid and sulphate; $10 \%$ of the dose is excreted as an ethereal sulphate.
4. $p$-Acetotoluidide is virtually completely oxidized to $p$-acetamidobenzoic acid, $10 \%$ being excreted as ester glucuronide. There is no conjugation with sulphuric acid.

5. $o$ - and $m$-acetotoluidides cause an abnormally high excretion of reducing material in urine. The reason for this has not been determined.

The sulphate estimations were carried out by $\mathrm{Mr} \mathrm{P}$. B. Wood, to whom the authors' thanks are due. We are also indebted to the Royal Society for a Government Grant which defrayed part of the cost of the investigation.

\title{
REFERENCES
}

Bratton, A. C. \& Marshall, E. K., Jr. (1939). J. biol. Chem. 128, 537.

Bray, H. G., Lake, H. J., Neale, F. C., Thorpe, W. V. \& Wood, P. B. (1948). Biochem. J. 42, 434.

Bray, H. G., Neale, F. C. \& Thorpe, W. V. (1946a). Biochem. J. 40, 134.

Bray, H. G., Neale, F. C. \& Thorpe, W. V. (1946b). Biochem. J. 40, 406.

Bray, H. G., Ryman, B. E. \& Thorpe, W. V.(1947). Biochem. J. 41, 212.
Folin, 0. (1905-6). J. biol. Chem. 1, 131.

Hammerbacher, F. (1884). Pflüg. Arch. ges. Physiol. 33, 94.

Hodgson, H. H. \& Beard, H. G. (1925). J. chem. Soc. 127, 498.

Jaffe, M. \& Hilbert, P. (1888). Hoppe-Seyl. Z. 12, 295.

Kleine, F. K. (1896-7). Hoppe-Seyl. Z. 22, 327.

Noelting, E. \& Cohn, B. (1884). Ber. dtsch. chem. Ges. 17, 352.

Sandmeyer, T. (1886). Ber. dtsch. chem. Ges. 19, 2656.

Williams, R. T. (1947). Biochem. J. 41, 1.

\section{Studies in the Biochemistry of Micro-organisms}

\section{THE MOLECULAR CONSTITUTION OF MYCOPHENOLIC ACID, A METABOLIC PRODUCT OF PENICILLIUM BREVI-COMPACTUM DIERCKX}

\section{PART 2. POSSIBLE STRUCTURAL FORMULAE FOR MYCOPHENOLIC ACID}

\author{
By J. H. BIRKINSHAW, A. BRACKEN, E. N. MORGAN AND H. RAISTRICK \\ Division of Biochemistry, London School of Hygiene and Tropical Medicine, University of London
}

\section{(Received 4 February 1948)}

Mycophenolic acid, $\mathrm{C}_{17} \mathrm{H}_{20} \mathrm{O}_{6}$, was first named and isolated from cultures of Penicillium stoloniferum Thom by Alsberg \& Black (1913), although Gosio (1896) had reported an unnamed crystalline metabolic product of ' $P$. glaucum', to which he assigned the formula $\mathrm{C}_{9} \mathrm{H}_{10} \mathrm{O}_{3}$, which is probably identical with mycophenolic acid. Clutterbuck, Oxford, Raistrick \& Smith (1932) isolated mycophenolic acid, together with other phenolic compounds, from the culture filtrates of twelve species or strains in the $P$. brevi-compactum series, to which $P$. stoloniferum Thom belongs, and Clutterbuck \& Raistrick (1933) reported an extensive chemical investigation of this substance.

Gosio (1896) demonstrated that his substance, $\mathrm{C}_{9} \mathrm{H}_{10} \mathrm{O}_{3}$, suppresses the growth of the anthrax bacillus, so that it appears probable that mycophenolic acid, although of relatively low potency, was the first antibiotic of fungal origin to be obtained in crystalline form. More recently, Florey, Gilliver, Jennings \& Sanders (1946) investigated its antibacterial action against a number of animal and plant pathogens and also against a number of saprophytic and pathogenic fungi. They showed that it is more effective against Gram positive than against Gram negative bacteria and that its activity against staphylococci varies greatly with the number of organisms used for the inoculum. This 'inoculum size' phenomenon was thoroughly investigated by Abraham (1945).

Clutterbuck \& Raistrick (1933) established, inter alia, the following facts bearing on the constitution of mycophenolic acid:

(1) It is optically inactive.

(2) The six oxygen atoms are present in the molecule in the following forms : (a) One as a $\mathrm{OCH}_{3}$ group. On demethylation, normycophenolic acid, $\mathrm{C}_{16} \mathrm{H}_{18} \mathrm{O}_{6}$, is formed. (b) One as a phenolic $\mathrm{OH}$ group, re- 